\title{
Non-specificity of sequence characterised amplified region as an alternative molecular epidemiology marker for the identification of Salmonella enterica subspecies enterica serovar Typhi
}

\author{
Ja'afar Nuhu Ja'afar ${ }^{1,2^{*}}$, Subhash Janardhan Bhore ${ }^{3}$ and Kia Kien Phua ${ }^{{ }^{*}}$
}

\begin{abstract}
Objective: Identification of Salmonella Typhi by conventional culture techniques is labour-intensive, time consuming, and lack sensitivity and specificity unlike high-throughput epidemiological markers that are highly specific but are not affordable for low-resource settings. SCAR, obtained from RAPD technique, is an affordable, reliable and reproducible method for developing genetic markers. Hence, this study investigated the use of SCAR as an alternative molecular epidemiological marker for easy identification of $S$. Typhi in low-resource settings.

Results: One hundred and twenty RAPD primers were screened through RAPD-PCR against a panel of common enterobacteriaceae for the best RAPD band pattern discrimination to develop SCAR primers that were used to develop a RAPD-SCAR PCR. Of this number, 10 were selected based on their calculated indices of discrimination. Four RAPD primers, SBSA02, SBSA03, SBSD08 and SBSD1 1 produced suitable bands ranging from 900 to 2500 bp. However, only SBSD11 was found to be specific for S. Typhi, and was cloned, sequenced and used to design new SCAR primers. The primers were used to amplify a panel of organisms to evaluate its specificity. However, the amplified regions were similar to other non-Typhi genomes denoting a lack of specificity of the primers as a marker for S. Typhi.
\end{abstract}

Keywords: SCAR, RAPD, S. Typhi, Kelantan, Malaysia

\section{Introduction}

Typhoid fever, a systemic disease caused by the bacterium Salmonella enterica subspecies enterica serovar Typhi ( $S$. Typhi), is global in distribution but more prevalent in Oceania, Africa, Latin America and Asia with prevalence rates of $15.4,49.8,53.1$, and 274.3 per 100,000 population, respectively [1].

For $S$. Typhi identification and genotyping, conventional culture techniques are labour intensive, time consuming, expensive, and lack sensitivity and specificity $[2$,

\footnotetext{
*Correspondence: jnjaafar@yahoo.com; kkphua7@mail.com

${ }^{1}$ Enteric Diseases Research Cluster, Institute for Research in Molecular Medicine (INFORMM), Universiti Sains Malaysia, 11800, USM George Town, Penang, Malaysia

Full list of author information is available at the end of the article
}

3]. In fact, epidemiologically unrelated $S$. Typhi isolates are often so similar and look identical using most typing techniques [4]. On average, an estimated time span of 4-7 days is required to obtain a positive result, excluding the time for serotyping $[5,6]$. Currently, high throughput epidemiological markers such as pulse-field gel electrophoresis (PFGE) and single nucleotide polymorphism (SNP) markers are employed to track and monitor $S$. Typhi and the disease it causes [7-9]. However, these markers are expensive to develop and are not readily affordable in low-resource settings where the disease is mostly endemic.

Random amplified polymorphic DNA-PCR (RAPDPCR) is a rapid and sensitive PCR method that enables the amplification of independent genetic loci of the target 
genome. It has been developed for genetic mapping, fingerprinting, and is widely used in inter- and intra- specific population polymorphism analyses of different organisms [10]. It has proved to be a powerful tool for discriminating different species or subspecies of organisms, and for genetic analysis or phylogenetic relationships among strains for a variety of microorganisms, plants, and mammals $[11,12]$. In addition, it has been used for strain discrimination in various $S$. enterica serovars [1316]. However, this method has an underlying disadvantage of being less reliable due to its sensitivity to reaction parameters such as quality of DNA template, concentrations of PCR components and PCR cycling conditions $[17,18]$. Sequence characterised amplified region (SCAR) is derived by converting RAPD markers through cloning and sequencing the two ends of the amplified polymorphic RAPD fragments [19]. SCAR markers are more reliable, efficient and advantageous than RAPD markers because they are reproducible, less sensitive to reaction parameters and able to detect a single locus. Hence, these qualities allowed its use as a genetic marker [19-21].

Because of the known irreproducible nature of RAPD-PCR as a genotyping method within the scientific community, RAPD-SCAR using a pair of specific oligonucleotide primers derived from RAPD-PCR was explored. Although successfully used in plant and animal studies [22-26], the technique has been transferred to bacteria with varying degrees of successes. Hence, the present study was designed to investigate the possibility of developing SCAR marker as an alternative epidemiological marker for easy identification of $S$. Typhi in lowresource settings.

\section{Main text \\ Methods \\ Bacteria isolates}

A panel of 26 genomic DNA samples were used in this study. Sixteen $S$. Typhi isolates, previously differentiated by pulsed-field gel electrophoresis (PFGE) and differing in district and year of isolation [27, 28], were obtained from Hospital Universiti Sains Malaysia (HUSM), Kubang Kerian, Kelantan. The other ten isolates were either purchased from the American Type Culture Collection (ATCC) or obtained from the Biobank of the Institute for Research in Molecular Medicine (INFORMM), USM, Kelantan. These include Salmonella Paratyphi A (ATCC 9150), Salmonella Paratyphi B (ATCC BAA 1250), Salmonella Paratyphi C (ATCC 9068), Salmonella Typhimurium (ATCC 14028), Salmonella Poona (ATCC 04840), Salmonella Enteritidis (ATCC 13076), Shigella sonnei, Yersinia enterocolitica, Klebsiella pneumoniae and Escherichia coli.

\section{Genomic DNA extraction}

This was achieved using QIAGEN ${ }^{\circledR}$ DNA extraction kit, (DNeasy ${ }^{\circledR}$ Blood and Tissue Kit, USA). DNA concentration was measured using nanodrop (NANODROP 2000c, USA).

\section{RAPD primers}

Six kits of RAPD primers, (SBS A-F from SBS Genetech Co., Ltd. China), containing 20-decamer oligonucleotides each, were used. The primers have melting temperatures $(\mathrm{Tm})$ of either $32{ }^{\circ} \mathrm{C}$ or $34{ }^{\circ} \mathrm{C}$ with a GC content of $60 \%$ or $70 \%$, respectively.

\section{Screening and selection of RAPD primers}

All six kits (SBS A-F) were screened to select primers that have the best pattern discrimination. The optimized RAPD-PCR method [29] and three random $S$. Typhi isolates that had been previously differentiated using PFGE were used for the screening. A criterion was set by calculating the index of discrimination, defined as the ratio of maximum number of bands to minimum number of bands for the three isolates. Furthermore, an additional criterion was set for primers with the least ratio scores, which is "a primer with least ratio score that has higher maximum number of bands will be selected over a primer with lower maximum number of bands". Therefore, 10 primers were selected for subsequent RAPD-PCR screening of the 26 isolates.

\section{RAPD-PCR assay}

The optimised RAPD-PCR method of Ja'afar et al. [29] was adopted while the method of Melotto et al. [30] was adopted for SCAR marker development.

\section{Gel purification, cloning and sequencing of RAPD-PCR product}

Clear RAPD bands that were only present in S. Typhi were gel-purified using QIAGEN $^{\circledR}$ gel extraction kit (QIAquick ${ }^{\circledR}$ Gel Extraction Kit, USA) and cloned using QIAGEN $^{\circledR}$ cloning kit (QIAGEN ${ }^{\circledR}$ PCR Cloning ${ }^{\text {plus }}$ Kit, USA). Plasmids of positive clones were extracted using QIAGEN ${ }^{\circledR}$ plasmid extraction kit (QIAprep ${ }^{\circledR}$ Spin Miniprep Kit, USA) and sent to First BASE Laboratories Sdn. Bhd., Malaysia for sequencing. 


\section{Primer design and validation of SCAR primers}

Sequence homology search for each sequence was performed within GenBank's database [31] and unique primers were designed, synthesized and validated.

\section{Results}

\section{Selected RAPD primers}

The number of PCR bands was based on amplification of three selected S. Typhi isolates (STY083 (ATCC 7251), STY088 and STY231) that had been previously differentiated by pulsed-field gel electrophoresis (PFGE). Primers with high ratio scores had both high and low number of bands in at least two of the three isolates (Fig. 1a). It does not mean that the primer yielded higher number of bands in all isolates. In fact, primers with higher or equal number of bands in all isolates had low ratio scores (Fig. 1b). Conversely, primers with least ratio scores had no amplification in at least one of the isolates (Fig. 1c). In such instance, they were scored for the isolate(s) that had at least one band only.

\section{RAPD-PCR bands selection}

Out of the ten RAPD primers, four (SBSA02, A03, D08 and D11) produced suitable bands (ranging from 900 to 2500 bp) for SCAR marker development (Fig. 2a-d).

\section{RAPD-PCR product cloning}

Eluted DNA of the three $S$. Typhi isolates from each of the four primers above (12 in total) were used for cloning reactions. Only the three DNA products from primer SBSD11 that produced positive clones were sent for sequencing.

\section{Primer design for SCAR markers}

Sequencing results from both T7 and SP6 promoter regions of the pDrvie plasmid provided the sequence composition of the cloned DNA fragment. The sequences were bioinformatically stringed using MEGA software (Version 5.2, [32]). Blasting the sequence against the nonredundant database of NCBI showed that it encodes a Type IV secretory pathway protein, virB4 component and a lipoprotein in $S$. Typhi and a hypothetical protein in $S$. Typhimurium.

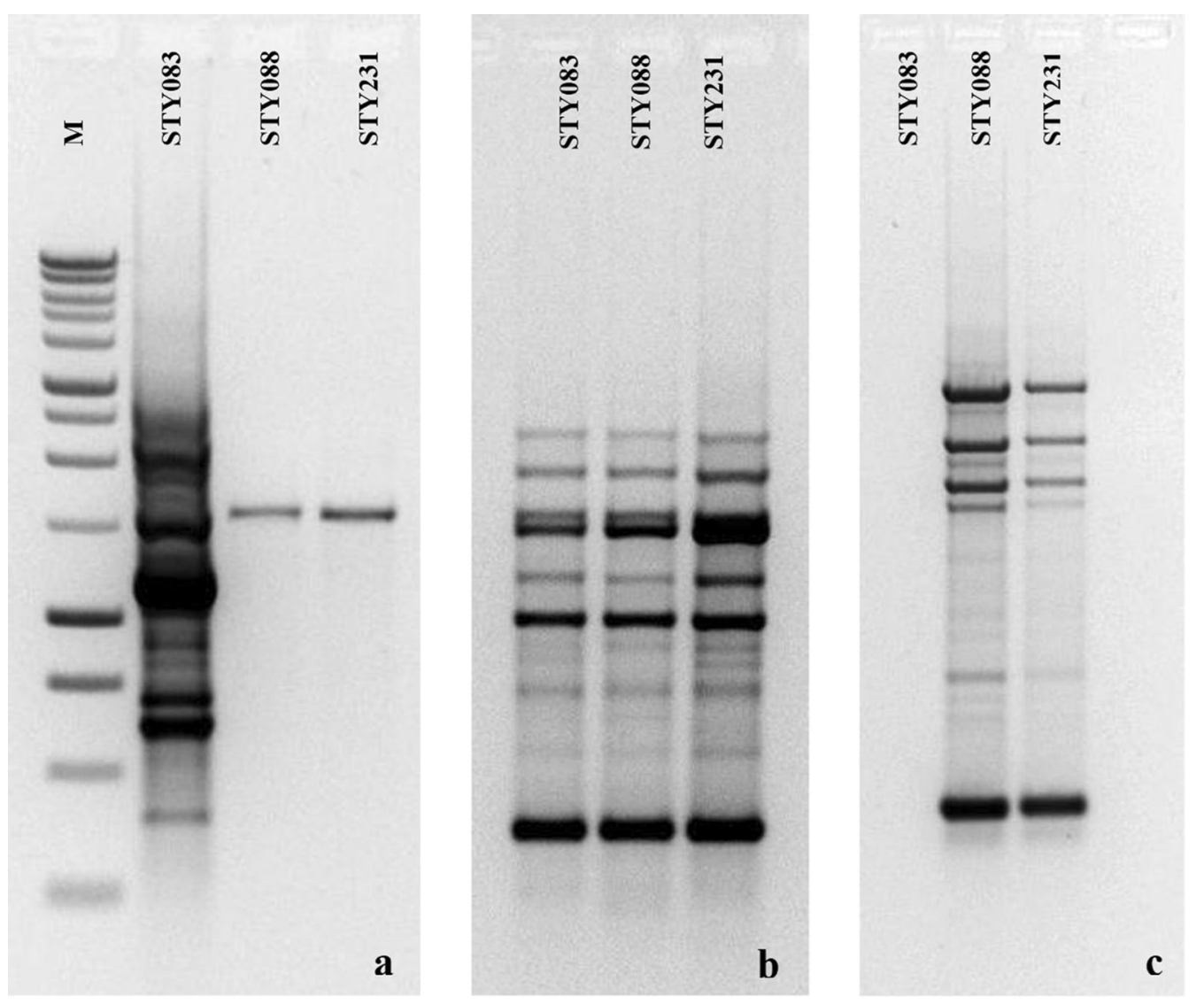

Fig. 1 Example of scoring for different primers. Primers had both high and low bands in at least two isolates (a); equal number of bands in all isolates (b); no amplification in at least one isolate (c). M: Marker; STY083, STY088 and STY231: S. Typhi isolates 

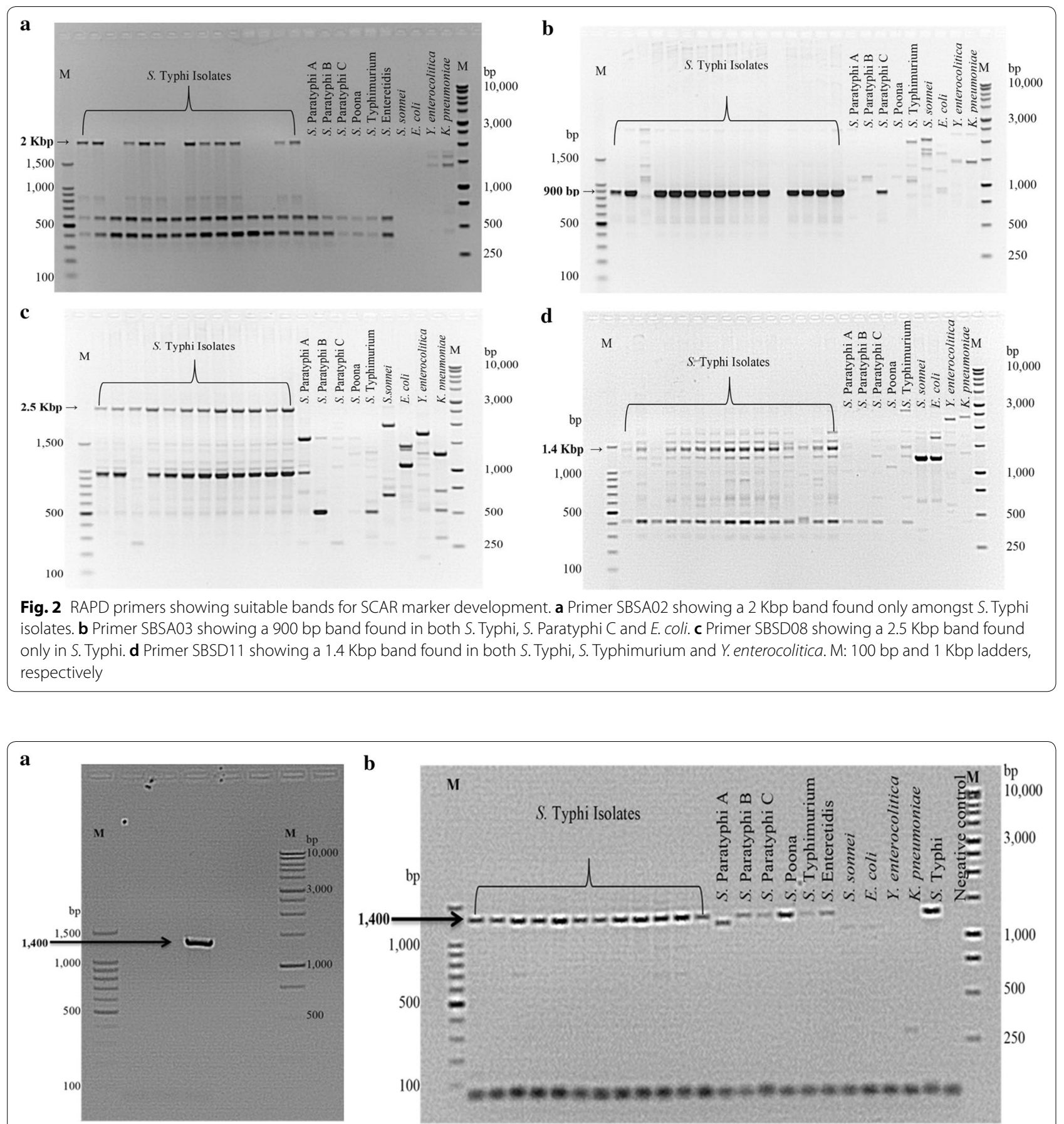

Fig. 3 a Optimized SCAR-PCR assay using recombinant pDrive plasmid as DNA template. Optimum annealing temperature was $56^{\circ} \mathrm{C}$. M: $100 \mathrm{bp}$ and $1 \mathrm{Kbp}$ ladders, respectively. b Gel showing results of PCR assay using specific SCAR primer. M: 100 bp and 1 Kbp ladders, respectively

\section{Validation of SCAR primers}

The recombinant $\mathrm{pDrive}$ plasmid was used as template DNA to optimize both annealing temperature and PCR reaction conditions of the synthesized primers (Fig. 3a). Following optimization, the primer was used to amplify the panel of organisms for confirmation. However, the amplified regions were similar to other non-Typhi genomes denoting lack of specificity of the primer as a marker for $S$. Typhi (Fig. 3b). 


\section{Discussion}

In an effort to develop a simple, fast and cost effective molecular epidemiology marker for identifying $S$. Typhi from other Salmonella species, 120 random primers were screened through RAPD-PCR against a panel of common enterobacteriaceae to develop SCAR primers that were used for RAPD-SCAR PCR.

During RAPD primer screening, some inconsistent amplifications were observed. In some instances, no bands were seen for certain primers, while some generate complex band patterns that were difficult to interpret. These sorts of inconsistencies have been reported previously whereby no amplification, difficult to interpret complex patterns, and primer artefacts, were observed $[33,34]$. More so, lack of amplification observed with some primers could be attributed, theoretically, to the distance of the primers on the $5^{\prime}$ and $3^{\prime}$ directions on the template DNA. A distance of more than $4 \mathrm{kbp}$ between the primers on the $5^{\prime}$ and $3^{\prime}$ directions has been reported to result in no amplification [35].

RAPD-PCR screening of bands for SCAR marker development was done using four primers, SBS-A02, -A03, -D08 and -D11, with suitable bands ranging from 900-2500 bp (Fig. 2a-d). Following cloning, only primer SBSD11 produced positive clones that were sent for sequencing. A specific SCAR primer set was designed for this sequenced fragment. The SCAR primer had, in addition, the original RAPD primer sequence in order to confirm the fragment's specificity to $S$. Typhi. After PCR optimization with the SCAR primer (Fig. 3a), another PCR was performed on the same panel of bacteria (Fig. 3b). The procedure was successful as it was able to identify all $S$. Typhi isolates. However, other subspecies enterica were also amplified though non-salmonella isolates such as E. coli, Y. enterocolitica and K. pneumoniae were not amplified (Fig. $3 \mathrm{~b}$ ). Inference to this phenomenon was drawn through published literatures. First, it could be explained by the fact that the isolates tested were all from the same subspecies, enterica, and that they share similar genetic content [36]. It has been reported that the serovars Typhi and Typhimurium share genetic homology in important pathogenicity elements [37]. Similarly, Parkhill et al. [38] has demonstrated that of the 204 pseudogenes present in $S$. Typhi, 75 of them were involved in housekeeping functions in other serovars. Pseudogenes are genes that have lost functions due to insertions, deletions or substitutions [38]. Furthermore, Chan et al. [39] have shown the close relationship of serovar Typhi to serovars Paratyphi A and Sendai in a microarray study. In the same manner, high similarity in gene contents has been reported for serovar Typhi strain CT18 and serovar Paratyphi A strain ATCC 9150 [40]. Therefore, the SCAR primer designed in this study may anneal to target sequences found in closely related serovars. Affirmatively, Aksoy [41], when identifying SCAR markers for $S$. Typhimurium, reported similar findings to this work. In the study, the $700 \mathrm{bp}$ band found to be specific to $S$. Typhimurium by RAPD-PCR could not be used for further studies.

However, successful use of SCAR markers has been reported for Trypanosoma cruzi [42] most probably due to the conservative nature of its genome and for the analysis of genomic instability in breast cancer tissues [43]. Other successful applications of SCAR markers have been for the detection of Agrobacterium vitis in rice [44], Pseudomonas brassicacearum as a biological control agent of snow mould in winter wheat [20] and Xylella fastidiosa in grape vine disease [45]. Similarly, it has been utilised in the identification of strawberry genotypes carrying red stele resistance gene for mass breeding [46, 47], preservation of an endangered ornamental tree species [48] and for adulteration detection $[49,50]$.

\section{Conclusion}

Although the SCAR marker developed in this study to specifically identify $S$. Typhi was successful, yet other serovars of the subspecies enterica were also amplified, suggesting the limited specificity of SCAR markers as alternative to the gold-standard, PFGE, in the identification of S. Typhi. However, the marker developed could instead, be used as a preliminary screening tool for Salmonella enterica subspecies rather than identifying a specific Salmonella serovar due to homologous nature of their genomes. More so, more research on this topic needs to be done to preclude the use of SCAR markers in Salmonella species.

\section{Limitations}

The need for stringent thermocycling conditions for RAPD assay optimization, limits the speed of SCAR development for $S$. Typhi even though the assay is low cost. Similarly, laboratory differentiation of isolates in closely related species, such as Salmonella enterica, is difficult due to sequence homology of their genomes.

\section{Abbreviations}

SCAR: sequenced characterized amplified region; RAPD: random amplified polymorphic DNA; PCR: polymerase chain reaction; PFGE: pulsed-field gel electrophoresis; HUSM: Hospital Universiti Sains Malaysia; INFORMM: Institute for research in molecular medicine.

\section{Authors' contributions}

JNJ designed the study, performed the experiments and wrote the first draft of the manuscript. SJB managed the literature searches and analysed the results of the study. KKP designed the study and wrote the final draft of the manuscript. All authors read and approved the final manuscript. 


\begin{abstract}
Author details
${ }^{1}$ Enteric Diseases Research Cluster, Institute for Research in Molecular Medicine (INFORMM), Universiti Sains Malaysia, 11800, USM George Town, Penang, Malaysia. ${ }^{2}$ Department of Biotechnology, School of Life Sciences, Modibbo Adama University of Technology (MAUTECH), Yola PMB 2076, Adamawa State, Nigeria. ${ }^{3}$ Department of Biotechnology, Faculty of Applied Sciences, AIMST University, 08100 Bedong, Kedah, Malaysia.
\end{abstract}

\section{Acknowledgements}

The authors would like to acknowledge the support of Hospital Universiti Sains Malaysia and INFORMM for providing the isolates used in this study.

\section{Competing interests}

The authors declare that they have no competing interests.

\section{Availability of data and materials}

The datasets used and/or analysed during the current study are available from the corresponding author on reasonable request.

\section{Consent for publication}

Not applicable.

\section{Ethics approval and consent to participate}

Not applicable.

\section{Funding}

We wish to acknowledge the financial support provided by Universiti Sains Malaysia (USM) in the form of Postgraduate Research Grant (PRGS) (Grant No. 1001/CIPPM/844078) and the Research University Cluster (RUC) project (Grant No. 1001/PSKBP/86300111). Note that funders had neither any role in study design nor data collection, analysis and manuscript preparation.

\section{Publisher's Note}

Springer Nature remains neutral with regard to jurisdictional claims in published maps and institutional affiliations.

\section{Received: 28 August 2018 Accepted: 19 October 2018}

Published online: 29 October 2018

\section{References}

1. Crump JA, Luby SP, Mintz ED. The global burden of typhoid fever. Bull World Health Organ. 2004;82:346-53.

2. Bohaychuk VM, Gensler GE, King RK, Wu JT, McMulllen LM. Evaluation of detection methods for screening meat and poultry products for the presence of foodborne pathogens. J Food Prot. 2005;68(12):2637-47.

3. Oliveira S, Rodenbusch C, Ce M, Rocha S, Canal C. Evaluation of selective and non-selective enrichment PCR procedures for Salmonella detection. Lett Appl Microbiol. 2003;36(4):217-21.

4. Roumagnac P, Weill F-X, Dolecek C, Baker S, Brisse S, Chinh NT, Le TAH, Acosta CJ, Farrar J, Dougan G. Evolutionary history of Salmonella Typhi. Science. 2006;314(5803):1301-4.

5. Jin U-H, Cho S-H, Kim M-G, Ha S-D, Kim K-S, Lee K-H, Kim K-Y, Chung $\mathrm{DH}$, Lee $\mathrm{Y}-\mathrm{C}$, Kim C-H. PCR method based on the ogdH gene for the detection of Salmonella spp. from chicken meat samples. J Microbiol. 2004;42(3):216-22.

6. Seo K-H, Holt PS, Stone HD, Gast RK. Simple and rapid methods for detecting Salmonella Enteritidis in raw eggs. Int J Food Microbiol. 2003;87(1-2):139-44

7. Holt KE, Parkhill J, Mazzoni CJ, Roumagnac P, Weill F-X, Goodhead I, Rance R, Baker S, Maskell DJ, Wain J. High-throughput sequencing provides insights into genome variation and evolution in Salmonella Typhi. Nat Genet. 2008;40(8):987.

8. Holt KE, Baker S, Dongol S, Basnyat B, Adhikari N, Thorson S, Pulickal AS, Song Y, Parkhill J, Farrar JJ. High-throughput bacterial SNP typing identifies distinct clusters of Salmonella Typhi causing typhoid in Nepalese children. BMC Infect Dis. 2010;10(1):144.

9. Holt KE, Dutta S, Manna B, Bhattacharya SK, Bhaduri B, Pickard DJ, Ochiai RL, Ali M, Clemens JD, Dougan G. High-resolution genotyping of the endemic Salmonella Typhi population during a Vi (typhoid) vaccination trial in Kolkata. PLoS Negl Trop Dis. 2012;6(1):e1490.

10. Galvão LM, Lages-Silva E. Randomly amplified polymorphic DNA (RAPD): a useful tool for genomic characterization of different organisms. In: Walker JM, Rapley R, editors. Molecular biomethods handbook. 2nd ed. Totowa: Humana Press; 2008. p. 133-47.

11. Caetano-Anolles G, Brant B. DNA amplification fingerprinting using very short arbitrary oligonucleotide primers. Nat Biotechnol. 1991;9(6):553.

12. Rafalski J, Tingey S, Willians J. RAPD markers-a new technology for genetic mapping and plant breeding. AgBiotech News Inf. 1991;3(4):645-48.

13. Chansiripornchai N, Ramasoota P, Bangtrakulnonth A, Sasipreeyajan J, Svenson SB. Application of randomly amplified polymorphic DNA (RAPD) analysis for typing avian Salmonella enterica subsp. enterica. FEMS Immunol Med Microbiol. 2000;29(3):221-5.

14. De Cesare A, Manfreda G, Dambaugh T, Guerzoni M, Franchini A. Automated ribotyping and random amplified polymorphic DNA analysis for molecular typing of Salmonella Enteritidis and Salmonella Typhimurium strains isolated in Italy. J Appl Microbiol. 2001;91(5):780-5.

15. Liebana E. Molecular tools for epidemiological investigations of S. enterica subspecies enterica infections. Res Vet Sci. 2002;72(3):169-75.

16. Yan SS, Pendrak ML, Abela-Ridder B, Punderson JW, Fedorko DP, Foley SL. An overview of Salmonella typing: public health perspectives. Clin Appl Immunol Rev. 2004;4(3):189-204.

17. Ellsworth D, Rittenhouse K, Honeycutt R. Artifactual variation in randomly amplified polymorphic DNA banding patterns. Biotechniques. 1993;14(2):214-7.

18. Tyler K, Wang G, Tyler S, Johnson W. Factors affecting reliability and reproducibility of amplification-based DNA fingerprinting of representative bacterial pathogens. J Clin Microbiol. 1997;35(2):339.

19. Paran I, Michelmore R. Development of reliable PCR-based markers linked to downy mildew resistance genes in lettuce. Theor Appl Genet. 1993;85(8):985-93.

20. Holmberg A-IJ, Melin P, Levenfors JP, Sundh I. Development and evaluation of SCAR markers for a Pseudomonas brassicacearum strain used in biological control of snow mould. Biological Control. 2009;48(2):181-7.

21. Trébaol G, Manceau C, Tirilly Y, Boury S. Assessment of the genetic diversity among strains of Xanthomonas cynarae by randomly amplified polymorphic DNA analysis and development of specific characterized amplified regions for the rapid identification of $X$. cynarae. Appl Environ Microbiol. 2001;67(8):3379-84.

22. Arnedo-Andrés M, Gil-Ortega R, Luis-Arteaga M, Hormaza J. Development of RAPD and SCAR markers linked to the PVr4 locus for resistance to PVY in pepper (Capsicum annuum L.). Theor Appl Genet. 2002;105(6-7):1067-74.

23. Bautista R, Cánovas FM, Claros MG. Genomic evidence for a repetitive nature of the RAPD polymorphisms in Olea europaea (olive-tree). Euphytica. 2003;130(2):185-90.

24. Koveza O, Kokaeva Z, Konovalov F, Gostimsky S. Identification and mapping of polymorphic RAPD markers of pea (Pisum sativum L.) genome. Russ J Genet. 2005;41(3):262-8.

25. Mariniello L, Sommella MG, Sorrentino A, Forlani M, Porta R. Identification of Prunus armeniaca cultivars by RAPD and SCAR markers. Biotech Lett. 2002;24(10):749-55.

26. Yuan Z, Yin Y, Qu J, Zhu L, Li Y. Population genetic diversity in Chinese pomegranate (Punica granatum L.) cultivars revealed by fluorescent-AFLP markers. J Genetics Genom. 2007;34(12):1061-71.

27. Goay YX, Chin KL, Tan CLL, Yeoh CY. Ja'afar JN, Zaidah AR, Chinni SV, Phua KK: Identification of five novel Salmonella Typhi-specific genes as markers for diagnosis of typhoid fever using single-gene target PCR assays. Biomed Res Int. 2016;2016:8905675.

28. Nur Fadhila K, Ja'afar JN, Hani MH, Zaidah AR, Prabha B, Asma I, Thong KL, Goering R, Phua KK. Pulsed-field gel electrophoresis analysis of Salmonella enterica serovar Typhi isolates in the north-east region of Peninsular Malaysia between 2002 and 2009. J Appl Life Sci Int. 2016:5(2):1-10.

29. Ja'afar JN, Bhore SJ, Prabha B, Phua KK. Optimization of random amplified polymorphic DNA-PCR for genotyping Salmonella enterica subspecies enterica serovar Typhi using a mathematical approach. J Sci Res Rep. 2016:11(1):1-9.

30. Melotto $M$, Afanador $L$, Kelly J. Development of a SCAR marker linked to the I gene in common bean. Genome. 1996;39(6):1216-9. 
31. Sayers EW, Barrett T, Benson DA, Bolton E, Bryant SH, Canese K, Chetvernin $V$, Church DM, DiCuccio M, Federhen S. Database resources of the national center for biotechnology information. Nucleic Acids Res. 2012;40(D1):D13-25.

32. Tamura K, Peterson D, Peterson N, Stecher G, Nei M, Kumar S. MEGA5: molecular evolutionary genetics analysis using maximum likelihood, evolutionary distance, and maximum parsimony methods. Mol Biol Evol. 2011;28(10):2731-9.

33. Demeke T, Adams R, Chibbar R. Potential taxonomic use of random amplified polymorphic DNA (RAPD): a case study in Brassica. Theor Appl Genet. 1992;84(7-8):990-4.

34. Echt C, Erdahl L, McCoy T. Genetic segregation of random amplified polymorphic DNA in diploid cultivated alfalfa. Genome. 1992;35(1):84-7.

35. Dassanayake RS, Samaranayake LP. Randomly amplified polymorphic DNA fingerprinting. PCR protocols. Berlin: Springer; 2003. p. 117-22.

36. Chain PS, Carniel E, Larimer FW, Lamerdin J, Stoutland P, Regala W, Georgescu A, Vergez L, Land M, Motin V. Insights into the evolution of Yersinia pestis through whole-genome comparison with Yersinia pseudotuberculosis. Proc Natl Acad Sci. 2004;101(38):13826-31.

37. Harris JB, Baresch-Bernal A, Rollins SM, Alam A, LaRocque RC, Bikowski M, Peppercorn AF, Handfield M, Hillman JD, Qadri F. Identification of in vivo-induced bacterial protein antigens during human infection with Salmonella enterica serovar Typhi. Infect Immun. 2006;74(9):5161-8.

38. Parkhill J, Dougan G, James K, Thomson N, Pickard D, Wain J, Churcher C, Mungall K, Bentley S, Holden M. Complete genome sequence of a multiple drug resistant Salmonella enterica serovar Typhi CT18. Nature. 2001:413(6858):848-52.

39. Chan K, Baker S, Kim CC, Detweiler CS, Dougan G, Falkow S. Genomic comparison of Salmonella enterica serovars and Salmonella Bongori by use of an S. enterica serovar Typhimurium DNA microarray. J Bacteriol. 2003:185(2):553-63.

40. McClelland M, Sanderson KE, Clifton SW, Latreille P, Porwollik S, Sabo A, Meyer R, Bieri T, Ozersky P, McLellan M. Comparison of genome degradation in Paratyphi A and Typhi, human-restricted serovars of Salmonella enterica that cause typhoid. Nat Genet. 2004;36(12):1268.

41. Aksoy C. Identification of serotype specific dna marker for Salmonella Typhimurium by RAPD-PCR method. Ankara: Middle East Technical University; 2004.

42. Brisse S, Dujardin J-C, Tibayrenc M. Identification of six Trypanosoma cruzi lineages by sequence-characterised amplified region markers. Mol Biochem Parasitol. 2000;111(1):95-105.

43. Singh KP, Roy D. Identification of novel breast tumor-specific mutation (s) in the q11. 2 region of chromosome 17 by RAPD/AP-PCR fingerprinting. Gene. 2001;269(1):33-43.

44. Lim SH, Kim JG, Kang HW. Novel SCAR primers for specific and sensitive detection of Agrobacterium vitis strains. Microbiol Res. 2009;164(4):451-60.

45. Travensolo RF, Ciapina LP, Lemos EG. Development of a scar marker for Pierce's Disease strains of Xylella fastidiosa. Fitopatol Brasileira. 2005;30(2):115-20.

46. Haymes K, Van de Weg W, Arens P, Maas J, Vosman B, Den Nijs A. Development of SCAR markers linked to a Phytophthora fragariae resistance gene and their assessment in European and North American strawberry genotypes. J Am Soc Hortic Sci. 2000;125(3):330-9.

47. Rugienius R, Siksnianas T, Stanys V, Gelvonauskiene D, Bendokas V. Use of RAPD and SCAR markers for identification of strawberry genotypes carrying red stele (Phytophtora fragariae) resistance gene Rpf1. Agron Res. 2006;4:335-9.

48. Ye Q, Qiu Y-X, Quo Y-Q, Chen J-X, Yang S-Z, Zhao M-S, Fu C-X. Speciesspecific SCAR markers for authentication of Sinocalycanthus chinensis. J Zhejiang Univ Sci B. 2006;7(11):868-72.

49. Dhanya K, Sasikumar B. Molecular marker based adulteration detection in traded food and agricultural commodities of plant origin with special reference to spices. Curr Trends Biotechnol Pharm. 2010:4:1.

50. Dhanya K, Syamkumar S, Siju S, Sasikumar B. SCAR markers for adulterant detection in ground chilli. Br Food J. 2011;113(5):656-68.
Ready to submit your research? Choose BMC and benefit from:

- fast, convenient online submission

- thorough peer review by experienced researchers in your field

- rapid publication on acceptance

- support for research data, including large and complex data types

- gold Open Access which fosters wider collaboration and increased citations

- maximum visibility for your research: over $100 \mathrm{M}$ website views per year

At $\mathrm{BMC}$, research is always in progress.

Learn more biomedcentral.com/submissions 